A N NALES

UNIVERSITATIS MARIAE CURIE-SKŁODOWSKA LUBLIN - POLONIA

VOL. XXIX, 4 SECTIO J 2016

Maria Curie-Skłodowska University in Lublin. Faculty of Education and Psychology

\author{
MARCIN CABAK
}

marcin.cabak@gmail.com

\title{
Personal Resources of Polish Emigrants on the European Labor Market
}

Zasoby osobiste emigrantów polskich na europejskim rynku pracy

\begin{abstract}
SUMMARY
Nowadays there is a tendency that people plan and carry on their career paths beyond borders of their homeland. Even though labor migration has become less risky than before, it requires vital changes in the lifestyle as well as having personal resources which can guarantee successful accomplishment of the individual plans. In the article, the author analyzes various aspects of personal resources of Polish labor emigrants in European Union countries.
\end{abstract}

Keywords: personal resources; labor migration; labor market

Labor migration has become a phenomenon of contemporary time. In the world, where globalization has become a fact, labor migration of work force is a natural reaction for dynamically changing labor market. People seek better life options and better career advancement. Migration processes within Europe and opening of most labor markets have created new opportunities for countries of lower economic development. Differences in earnings and standards of life result in migrations not only of unemployed people or those who do not foresee the chances of personal growth in their homeland but also well-educated professionals.

Important factors influencing successful career development in a foreign country are personal resources of labor emigrants. Those resources consist not 
only of individual features (biological, psychological, social and spiritual) but also environmental, social or cultural.

According to specialists, "Personal resource is a feature, possessed by emigrant, which turns into capital only if on the specific market the demand for such feature exists" (Grabowska-Lusińska, Okólski 2009, p. 147).

First of all, there are professional and social skills and abilities of individuals including, for example, age, sex, education, expressed in job competencies, language skills, motivation, resistance to work pressure, self-confidence, decisiveness, and job responsibility (cf. Giza-Poleszczuk, Marody, Rychard 2000).

Individual personal resources in a collective sense create human capital of post-accession immigrants. Therefore, its utilization (capitalization) plays vital role in their functioning on European labor market.

According to my research, most of the Polish emigrants belong to the young age group. Predominantly, there are people of the most mobile age (20-30 years), encouraging them to undertake work abroad. Male to female ratio in migration flows depends on their final destination. East of Europe is mainly chosen by females, whereas males choose to go to Western Europe. In post-accession migrations to Great Britain, however, the number of female immigrants is higher than that of male immigrants (Grabowska-Lusińska, Okólski 2009, pp. 147-148). According to the expertise made for the European Commission (Labour mobility within the EU... 2009), the greatest drain of workers employed in the EU took place after Romania, Poland, Bulgaria, Hungary and Slovakia joined the EU. Among immigrants from Mid-European countries the majority is well-educated. Therefore, such labor flow is an example of a typical "brain drainage". The highest percentage of people with higher education emigrates from the Czech Republic $36.7 \%$ ( $11.2 \%$ of people with higher education among the whole population), next from Hungary - 35.4\% (15\%, respectively), Lithuania 35.4\% (22.6\%, respectively). The following are Bulgaria: $30.2 \%$ (22.6\%, respectively) and Poland: $25.7 \%$ of emigrants with higher education and $14.7 \%$ of well-educated people within the whole population (Bera 2011a, pp. 22-23). Apart from that, those people are not afraid of taking risks, open for challenges and creative.

Even though Mid-European immigrants are usually well-educated, they accept lower salary and often worse working conditions in comparison with local citizens which makes them more competitive with other ethnic groups (Grabowska-Lusińska, Okólski 2009, p. 149). As much as two thirds of them get job offers where the requirements are lower than their qualification and not related to their professional education and experience. Such situation results in constant loss of knowledge and professional skills gathered during the education process (Bera 2008). In consequence, they seek employment in various lower market sectors, most often in construction, agriculture, processing industry, retail businesses, hotels and catering. 
The results of studies (Bera 2011a, pp. 185,191-195) show that Poles working abroad in EU countries are formally well prepared, although their education is not adequate to the job performed on the local market. Not many have been promoted to leading or managerial position and are usually low positioned within the institution hierarchy. Most work physically and have inferior positions. One of the key factors is also the ability to communicate. The language of the country of residence is well known only by one in four immigrants. Generally, low language skills are the main obstacles in undertaking more complicated, leadership-related jobs. Immigrants seem to be aware that their language skills need to be improved, since employers mainly price communicational competencies, practical skills in duty performance, learning abilities, precision, engagement and flexibility at work.

Analyzing the work incompetence and lack of knowledge among the immigrants functioning on the European labor market in relation to its requirements, I observed that low language skills, lack of formal qualifications proved with licenses and certificates are the most dissatisfying factors. It might be assumed that their current work experience seems to be inadequate and insufficient to enable them to reach full job development, be recognized and promoted, achieve leadership positions within work environment. Due to that fact most of them declare willingness for further job development, as in a critical situation they are the first to be made redundant, fired or forced to accept lower payments.

Such uncertain position of labor immigrants on the labor market does not influence their personal feeling of being in charge of their own lives and free to act as they choose. According to comparative studies on labor immigrants and people working in their homeland, those working abroad are functioning better professionally and seem to have better control over their work situation. They think that they create their life and professional development themselves. If they did not succeed they usually would not blame "bad luck". Facing obstacles they would rather work harder, seek better solutions and opportunities to accomplish their individual plan and reach their goal.

It seems that for Poles working in other EU countries plays one of the most important roles and is valued right after health, successful family life and good material conditions (cf. Bera 2008, 2012). Labor immigrants claim that hard work, engagement and dedication, even if the work itself is not very important, give great life satisfaction. They believe that good performance and efficiency sooner or later will bring gratification. However, according to research, the choice of work is mainly based on material aspect followed by the work character (duty description) and other aspects such as the lack of better options or the distance from the place of living (Bera 2012, pp. 193-194). Among other factors the highly priced are: permanent work contract, high income and good relations with other workers as well as with the management. Less important are leadership or influence on 
social environment. Factors which are less valued are also flexible working hours or a type of work which does not require much of engagement. However, only every fifth from the immigrants surveyed expresses over average motivation in reaching goals in international career. The average level of motivation shows one in eleven surveyed immigrants. The remaining two thirds of immigrants declare below average or low motivation.

Analyzing the goal reaching motivation indicators it has to be observed that three quarters of immigrants aim for perfection in social competition and is not afraid even though, they realize they may not succeed in the new professional and social environment. Emigration allows them "to be somebody", even if the beginnings are not easy and the local workers, who often are less competent and less efficient, have better chances for promotion than immigrants. Self-fulfilment and perfectionism as the personal professional development pathway declares one in four immigrants. Every second would even invest personal finances into that aim (cf. Bera 2011b, p. 374).

Comparative studies show (cf. Bera 2012) that migrating labor force expresses higher job responsibility versus those working in the country of origin.

Especially, if we take into consideration internalization of features typical for a responsible worker. They are such as: reliability, honesty and dignity, respecting moral and social codes in work environment, predictability, respecting laws, rules and regulations as well as respecting superiors. In immigrants' opinion job responsibility reflects self-respect. It is the result of internalized moral norms and values and is conscious-related showing individual sensitivity for good and evil. It also enables to differentiate virtues from vices. Immigrants believe that responsible worker should express full readiness for social judgement of their work performance.

However, feeling of responsibility does not allow for free choice in each and every situation according to personal preferences. Circumstances and consequences have to be considered which in some cases might lead to conformity - reacting according to circumstances against personal will. Most often emigrants are ready to be responsible for their job quality. They undertake such responsibility, even if it results from their job function and individual duties.

It also has to be observed that people working in EU countries have higher self-esteem than those working in the country of origin. It is manifested especially in relation to positive and useful actions. However, most declare that still there is not many things they might be proud of.

It might be concluded that immigrants present more positive attitude towards themselves than those working in the country of origin. Self-confidence and high self-esteem is very important while facing new challenges in a new country of residence and dynamic situation on the labor market. As a result, they are more 
willing to undertake unconventional activities, more optimistic, less prone to negative emotions and changing moods (Bera 2012, pp. 194-195).

Summarizing, immigration changes Poles. Living in another country is the source of new life experience, requires resistance to stress and the will to fight on the demanding labor market. Workers take full responsibility for their professional growth and development. They change the typical stereotype of a Pole functioning in Western Europe. Often they are presented as venturesome, resourceful, socially mobile, workaholics supporting families willing to reach financial stabilization as soon as possible.

They build up and enrich their culture capital, "subjected" as a result of self-improvement, gained thanks to new skills and experiences. They also build "objected" capital as certificates and licenses proving newly gained level of competence. Such capital becomes the base for the economic capital and demonstrates attractiveness of a worker on the labor market.

It appears, however, that to reach maximal financial profit, cultural and social values are being sacrificed. Family life and relations suffer. Children upbringing is often neglected, especially among those who have already started up the families. Family separations cause not only conflicts, problems with children but also endanger stability of relations. The problem of spiritual orphanhood is increasing (cf. Bera, Korczyński 2012, pp. 27-30).

Meanwhile, labor immigration releases many economic and social problems in the emigrant's homeland, and in the long-term perspective it may bring many dangers for its functioning and social and economic development. It is enough to mention: society ageing and instability of retirement pay system, insufficient number of specialists from different fields. The drain of specialist and professionals diminishes an option for the country to regain the costs of education and results in lower development of certain economic areas (cf. Denek 2010). Those people who decided to return to the country of their origin and who were more or less successful while abroad, bring with them not only the earned money but also elements of foreign culture.

Unfortunately, the expected massive returns from immigration do not happen. Generally, emigrants try to survive the crisis in the place of their temporary residence. They are convinced that regardless of current obstacles there is more guarantee for the accomplishment of their personal and professional plans abroad. 


\section{REFERENCES}

Bera R. (2008), Aksjologiczny sens pracy a poczucie jakości życia młodych emigrantów polskich, Lublin: Wydawnictwo UMCS.

Bera R. (2011a), Emigranci polscy w nowym środowisku pracy, Lublin: Wydawnictwo UMCS.

Bera R. (2011b), Motywacja osiagnięć zawodowych w karierze międzynarodowej osób migrujących zarobkowo, [in:] C. Plewka, H. Bednarczyk (red.), Człowiek - obywatel-pracownik na rynku pracy, Szczecin: Wydawnictwo WSH.

Bera R. (2012), Poczucie odpowiedzialności zawodowej osób migrujących zarobkowo. Perspektywa pedagogiczna, Lublin: Wydawnictwo UMCS.

Bera R., Korczyński M. (2012), Dystans społeczny emigrantów polskich wobec „obcych “ $i$, ,innych", Lublin: Wydawnictwo UMCS.

Denek K. (2010), Poakcesyjna migracja zarobkowa młodych Polaków w społeczeństwie wiedzy i jej skutki, [in:] R. Bera (red.), Wielka emigracja zarobkowa młodzieży. Wyzwania dla edukacji, Lublin: Wydawnictwo UMCS.

Grabowska-Lusińska I., Okólski M. (2009), Emigracja ostatnia?, Warszawa: Scholar.

Giza-Oleszczuk A., Marody M., Rychard A. (2000), Strategie i system. Polacy w obliczu zmiany społecznej, Warszawa: Wydawnictwo IFiS PAN.

Labour mobility within the EU in the context of enlargement and the functioning of the transitional arrangements (2009), www.igfse.pt/upload/docs/gabdoc/2009/Novidades/05-Mai/mobility09 backgr_rep_en.pdf (access: 10.12.2016).

\section{STRESZCZENIE}

Coraz częściej ludzie planują i realizują swoją karierę poza granicami własnego kraju. Mimo że emigracja zarobkowa nie jest już w takim stopniu, jak w przeszłości, naznaczona ryzykiem, to jednak wymaga istotnych zmian w życiu oraz posiadania określonych zasobów osobistych gwarantujących pomyślną realizację podjętych planów. Opracowanie stanowi przegląd badań dotyczących różnych aspektów zasobów osobistych polskich emigrantów zarobkowych do krajów Unii Europejskiej.

Słowa kluczowe: zasoby osobiste; emigracja zarobkowa; rynek pracy 